\title{
Implementation of PjBL-Based in Entrepreneurship Subject (Project Based Learning) during the Pandemic Period
}

\author{
Efa Wahyu Prastyaningtyas ${ }^{1}$, Widi Wulansari ${ }^{2}$ \\ ${ }^{1}$ Department of Economic Education, Nusantara PGRI University, Kediri, Indonesia \\ ${ }^{2}$ Early Childhood Teacher Education, Nusantara PGRI University, Kediri, Indonesia \\ Corresponding Author: Widi Wulansari
}

\begin{abstract}
This study objective is to determine the application of Project Based Learning in entrepreneurship subjects for students of the Elementary School Study Program, Universitas Nusantara PGRI of Kediri. This study used a quasi-experimental design with Posttest-Only Design with None equivalent Group. The population were 8 classes and simple random sampling technique was used to take the sample. Then, divide the sample into two categorized as students who already have a business and students who do not have one. In conclusion, the average score of students who have entrepreneurial experience is higher; it was 89.62 than the average score of students who do not have entrepreneurial experience with a score of 88.44 in PjBL-based Entrepreneurship learning. Thus, it can be interpreted that the implementation of PjBL-Based Entrepreneurship (Problem Based Learning) subjects for students who have entrepreneurial experience gives positive and significant results.
\end{abstract}

Keywords: Entrepreneurship subject, Project based learning, Pandemic

\section{INTRODUCTION}

The global crisis caused by COVID19 has an impact on increasing the number of unemployed. Data from Central Bureau of Statistics (CBS) for August 2020 shows that unemployment in Indonesia increased by $7.07 \%$, while in August 2019 it was $5.23 \%$. So, there was an increase in unemployment of $1.84 \%$ (CBS, 2020). The alternative solution to reduce this unemployment problem is most by increasing the number of entrepreneurs (Nazri, 2016). This is because entrepreneurship is the main driver in fostering innovation, creating jobs and being able to significantly grow the economy of a country (Badulescu \& Badulescu, 2013). Higher education as agents of change will certainly not remain silent, it will improve continually, especially dealing with courses which support students to prepare them to enter the community in the future, one of ways is through entrepreneurship subject.

Entrepreneurship subject is an effort made by university to provide entrepreneurship education to students so that they can internalize the entrepreneurial spirit and mentality through formal education. The role of entrepreneurship education according to (Cera et al., 2020) is a process of transferring knowledge to students in order to take advantage of business opportunities. Besides, entrepreneurship education has an important role to educate new entrepreneurs from both formal and non-formal education (Bae et al., 2014). And the main goal is to equip students, so that they can apply their knowledge in society by opening up opportunities after graduate by opening business and job opportunities for the community.

One of the universities that equip students with entrepreneurship subject is the 
Nusantara University PGRI of Kediri, especially in the Elementary School Study Program (ESSP). This course has been adapted as the vision and mission of the Study Program. Besides producing graduates to become competent elementary school teachers, it also prepares their students to become entrepreneurs. Entrepreneurship subject held at the Nusantara University PGRI of Kediri emphasize more on the basics of business which include planning, implementing, controlling, and developing business. Therefore, students will get collaborative learning experiences in the form of small projects to formulate business plans according to their scientific fields. However, the lectures that have been done offline so far cannot be conducted due to the pandemic caused by covid 19. This condition requires lecturer to conduct online teaching and learning activities. Online learning requires lecturers to think creatively and innovatively so that the learning process delivered is in accordance with the initial objectives of the lecture.

So, the learning model used by researchers in the implementation of online lectures is project based learning. This learning model is implemented by giving students the freedom to design, solve problems, make decisions, provide flexibility in finding and integrating tasks in the form of knowledge and experience from the activities in order completing student tasks (Rahmazatullaili et al., 2017). PjBL learning model is driven to foster soft skills like creative thinking, problem solving, innovation, teamwork, communication and presentation skills where students learn to collaborate with groups in planning activities, (Noviyana, 2017). Through PjBL learning, students will have direct experience with project-based activities so that they can produce certain products as a result of collaboration within groups' activities (Astini, Sari, 2020). The purpose of this study was to determine the implementation of PjBL (Project Based Learning)-based entrepreneurship subject during the pandemic at the PGSD Study Program, Universitas Nusantara PGRI of Kediri.

\section{LITERATURE REVIEW \\ Entrepreneurship Education}

Entrepreneurship education plays an important role in preparing students to become entrepreneurs (Bae et al., 2014). Crhrisman and McMullan (2020) also explained that the main purpose of entrepreneurship education is not only to foster entrepreneurial intentions, but furthermore it is to become entrepreneurs. Entrepreneurship education is covered in entrepreneurship subject; the objectives are to prepare students to become entrepreneurs through practice in business laboratories or in the field rather than just learning in class (George \& Bock, 2011). Practicing in the field allows students to have knowledge theoretically and direct practice.

The recent growth and development of curriculum and programs aimed at entrepreneurship and new venture creation is remarkable (Kuratko et al., 2020). According to (Saptono et al., 2020) Entrepreneurship education is a rapidly growing field and a hot topic in colleges and universities around the world, and its benefits have received much praise from researchers and educators. However, entrepreneurship education is still a debate because only a theory is given. This matter seems to put an obligation on starting entrepreneurship programs that help students achieve their aspirations and overcome their misconceptions. They stated that such educational programs need to be provided with learning opportunities that address the basic concepts and skills of entrepreneurship. They also need to clarify how these concepts and skills relate to competitive market systems and the public policy decisions that affect their operations.

\section{PjBL (Project Based Learning)}

Learning using the PjBL model will increase students' knowledge (Kadek et al., 2020), where students will be able to 
explore their abilities by collaborating with groups. This learning model has the advantage of developing student motivation, being able to improve problem solving, increasing collaboration and skills in finding and managing various sources of knowledge. While, the problem is the class difficult to control, the condition of the class is tend to be noisy, so teacher skills are needed in mastering and managing the class so that the teaching and learning process is conducive.

In addition, another weakness is that some students will be passive in groups because they have difficulty in the process of gathering information (Suciani et al., 2018). In this COVID-19 pandemic situation, all students are required to study from home so that the learning process is conducted online. In the implementation of this learning requires the use of information technology with the aim of helping students to actively participate the learning process flexibly anytime and anywhere. There are two types of this learning, they are: 1) Synchronous, where educators teach at the same time, so that there is direct interaction between educators and students. 2) Asynchronous, educators teach at different times. Students can carry out learning after the teacher provides the material (Astini, Sari, 2020).

\section{MATERIALS \& METHODS}

The research method used is quasiexperimental. The design used is PosttestOnly Design with none equivalent Group.

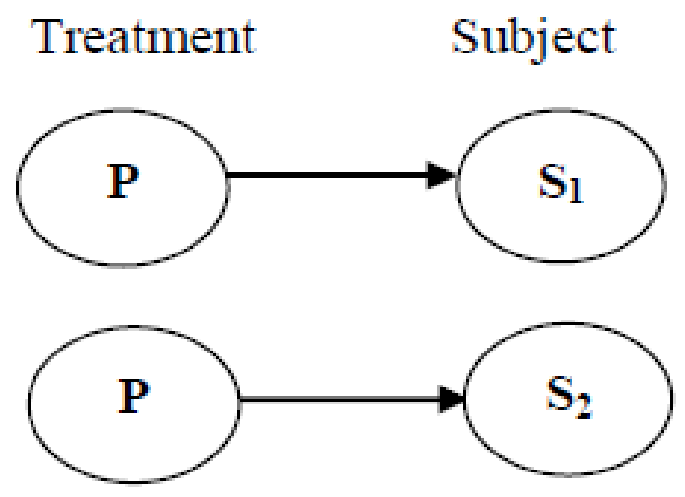

Figure 1. Research Design
The population in this study were PGSD Level 2 and 4 students who were taking Entrepreneurship courses which were divided into 8 classes. Simple Random Sampling was the sampling technique used, with PGSD students as the sample consisting of 92 students at IV level. The sample was divided into 2, students who already have entrepreneurial experience and do not have entrepreneurial experience. Data collection is done by using observation and tests.

Data analysis used was parametric statistics with Independent t-test. The steps taken by the researcher before testing the hypothesis were to test assumptions, which included normality test using the Kolmogorov-Smirnov test and homogeneity test using Levene's test.

\section{RESULT}

Entrepreneurship subject in PGSD Study Program are taken by students of $8^{\text {th }}$ semester (Level IV) class of 2017 and $4^{\text {th }}$ semester (Level II), where the learning outcomes formulated are emphasizing business basics which include planning, implementation, controlling, and business development. Therefore, students will get collaborative learning experiences in the form of small projects to formulate business plans according to their scientific fields. Preliminary observations that have been made by researchers on PGSD study program students Level IV and II show that $60 \%$ already have a business and $40 \%$ do not yet have a business. Where the results of business mapping that have been done by researchers for students are as follows:

Based on the preliminary business mapping diagram, it is found that $40 \%$ of students are in private tutoring business, $25 \%$ are selling online, $25 \%$ are culinary businesses and the remaining $10 \%$ are other businesses. From the results of the observations above, the teaching and learning process applied is not only a theory but also is a final project so that there is an increase in learning outcomes as seen from the following processes: 1) determining 
Efa Wahyu Prastyaningtyas et.al. Implementation of PjBL-based in entrepreneurship subject (project based learning) during the pandemic period.

business ideas, 2) product design, 3) the basis for the assessment carried out by production, 4) financial statements, 5) researchers to each student.

business feasibility. These five things are

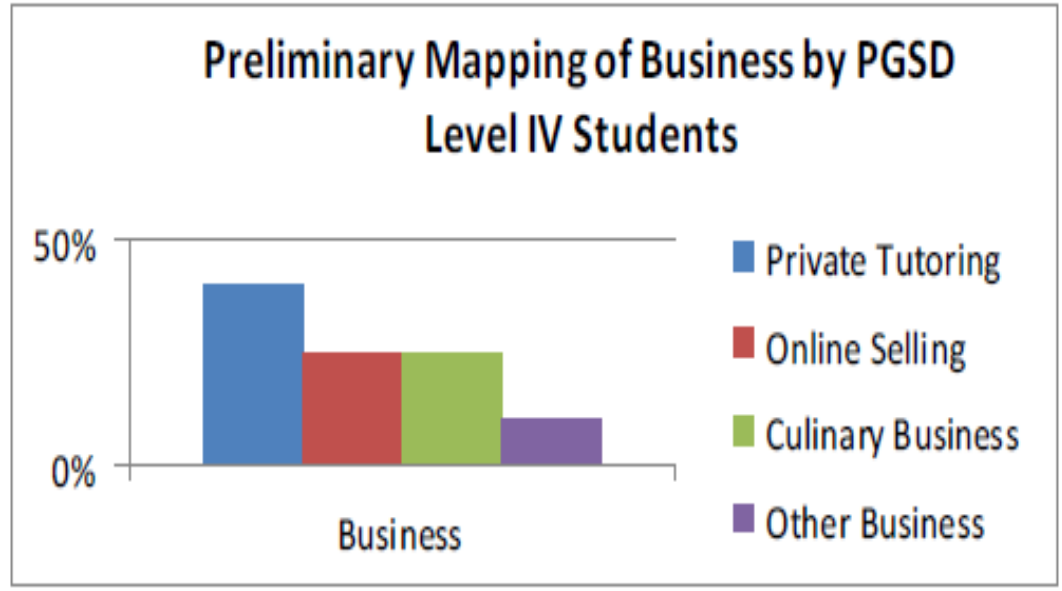

Diagram 1: Preliminary mapping of business by PGSD level IV students

Table 1. PGSD student learning outcomes even semester of 2020/2021

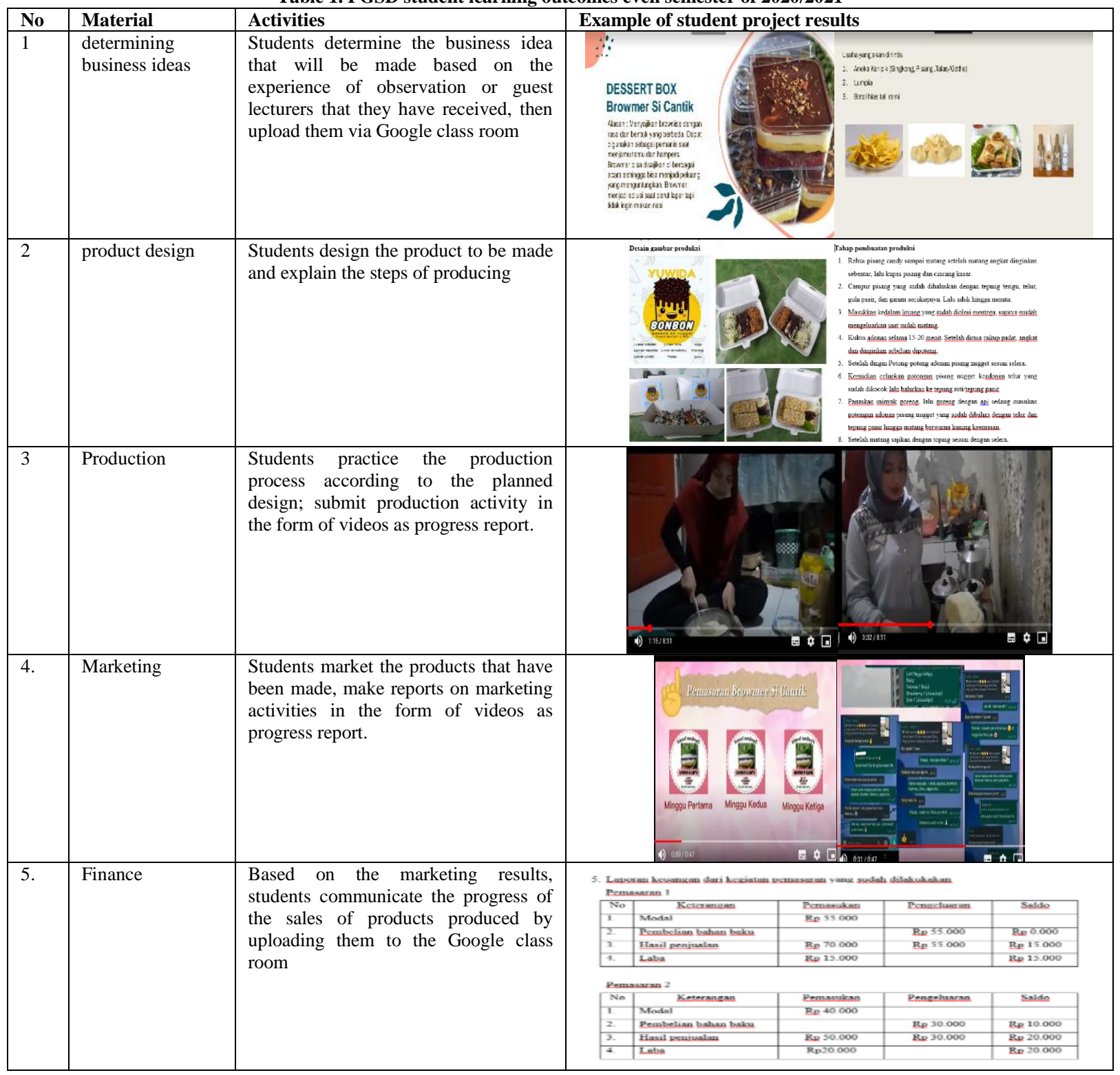




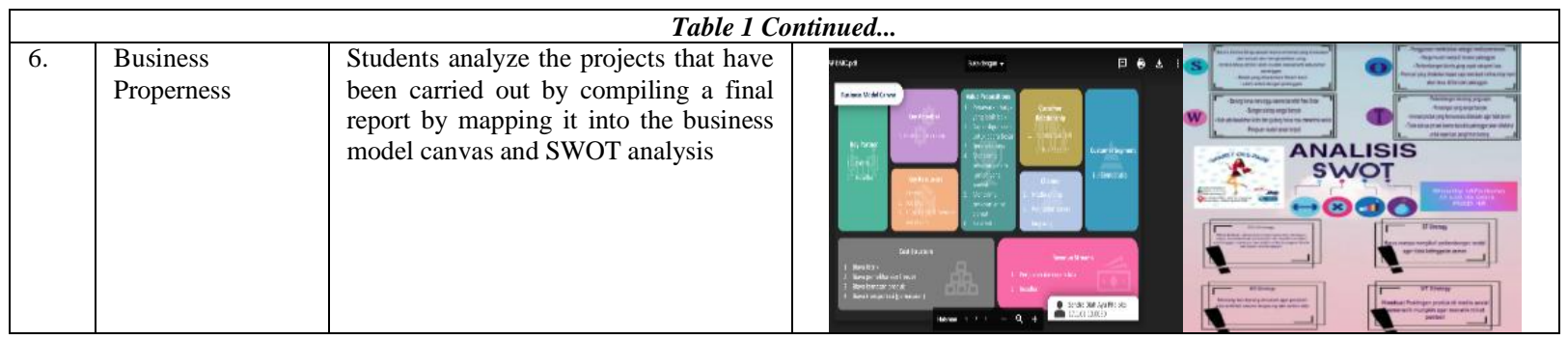

\section{a. Assumption Test}

\begin{tabular}{|l|l|l|l|}
\hline Tests & Score & Sig & Conclusion \\
\hline Normality_students who already have entrepreneurial experience & 1,162 & 0,134 & normal \\
\hline Normality_students who do not have entrepreneurial experience & 1,011 & 0,258 & normal \\
\hline Homogeneities & 1,547 & 0,217 & homogeny \\
\hline
\end{tabular}

Based on the test results in table 2, it can be concluded that the scores of students who already have business experience and those who do not have a normal and homogeneous distribution.

\section{b. Hypothesis testing}

After the assumption test can be met, it is possible to test the hypothesis. The hypothesis test used is the Independent ttest. The results of hypothesis testing with the help of the SPSS program are presented in table 2 .

Table 2 Independent Sample Test

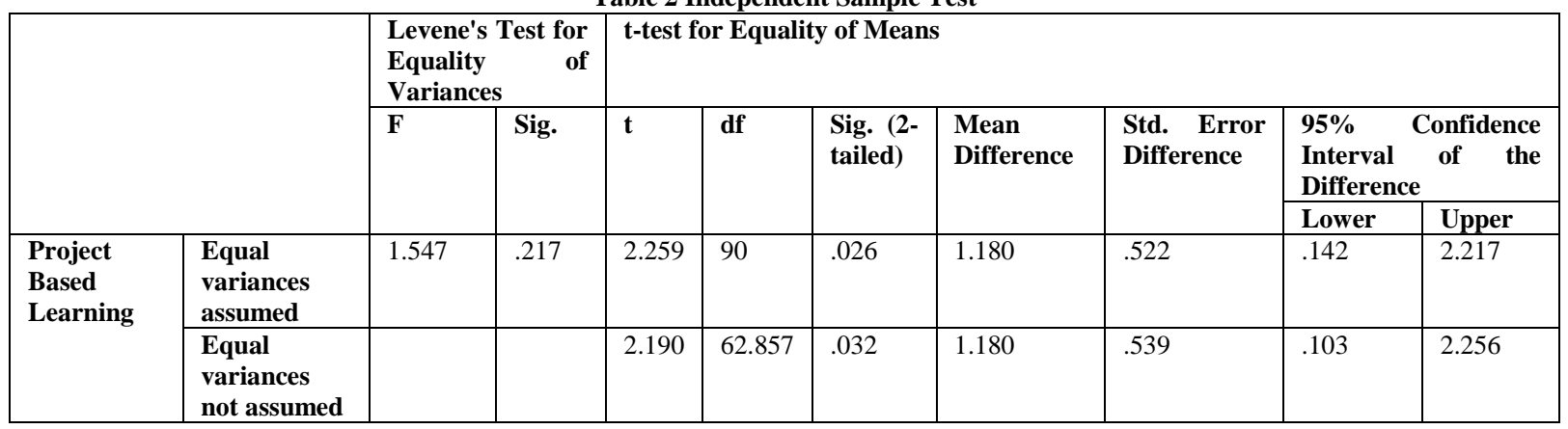

Considering at the Levene test results, the equal variances assumed is chosen

Based on the table, it can be seen that the sig value is 0.026 so that the sig value is less than the specified alpha value, which is 0.05 . The conclusion is that Ho is rejected and $\mathrm{Ha}$ is accepted.

Table 3. Group Statistics

\begin{tabular}{|l|l|l|l|l|l|}
\hline & Experience & $\mathbf{N}$ & Mean & Std. Deviation & Std. Error Mean \\
\hline \multirow{2}{*}{ entrepreneurial ability } & Experienced & 58 & 89.62 & 2.308 & .303 \\
\cline { 2 - 6 } & Not experienced & 34 & 88.44 & 2.596 & .445 \\
\hline
\end{tabular}

The results from the Group Statistics table show that the average value of students who have entrepreneurial experience is higher than the average value of students who do not have entrepreneurial experience in PjBL-based Entrepreneurship learning.

\section{DISCUSSION}

Based on the results of the implementation of PjBL-based entrepreneurship subject during the pandemic, it showed positive results because students were able to understand more about real entrepreneurship with direct practice starting from exploring business ideas, producing, marketing and compiling financial reports. Of course they will be more creative in coming up with every entrepreneurial idea. The advantage of this course is students can practice directly in a project. The results of the assumption test 
states that the samples taken as research subjects are normal and homogeneous. So, the sample is good to be used as a research subject. Based on the results of the hypothesis test, it is also stated that there is a difference between the average value of students who have entrepreneurial experience and students who do not have entrepreneurial experience in PjBL-based Entrepreneurship learning and the score increases. Thus, it can be interpreted that the implementation of PjBL-Based Entrepreneurship (Problem Based Learning) subject for students who already have entrepreneurial experience gives positive result and significant results.

\section{CONCLUSION}

The conclusions obtained from the results of research are:

1. Implementation of PjBL-based entrepreneurship subjects makes students understand more about good and useful entrepreneurship, starting from formulating business ideas, how to market products to compiling financial reports.

2. The average score of students who have entrepreneurial experience is better than the scores of students who do not have entrepreneurial experience so the application of learning with the PjBL method provides positive and significant results for students who have entrepreneurial experience.

\section{Acknowledgement: None}

\section{Conflict of Interest: None}

\section{Source of Funding: None}

\section{REFERENCES}

1. Astini, Sari, N. K. (2020). Pemanfaatan Teknologi Informasi dalam Pembelajaran Tingkat Sekolah Dasar pada Masa Pandemi Covid-19. Jurnal Lembaga Penjaminan Mutu STKIP Agama Hindu Amlapura, 11(2), 13-25.

2. Badulescu, A., \& Badulescu, D. (2013). How Entrepreneurial are Doctoral Students?
Some Evidence from Romania. Journal of Eastern Europe Research in Business and Economics, 2013, 1-10. https://doi.org/10.5171/2013.186798

3. Bae, T. J., Qian, S., Miao, C., \& Fiet, J. O. (2014). The Relationship Between Entrepreneurship Education and Entrepreneurial Intentions: A Meta-Analytic Review. Entrepreneurship: Theory and Practice, 38(2), 217-254. https://doi.org/10.1111/etap.12095

4. Cera, G., Mlouk, A., Cera, E., \& Shumeli, A. (2020). The impact of entrepreneurship education on entrepreneurial intention. A quasi-experimental research design. Journal of Competitiveness, 12(1), 39-56. https://doi.org/10.7441/joc.2020.01.03

5. George, G., \& Bock, A. J. (2011). The Business Model in Practice and its Implications for Entrepreneurship Research. Entrepreneurship: Theory and Practice, $35(1)$, 83-111. https://doi.org/10.1111/j.15406520.2010.00424.x

6. Kadek, N., Marta, D., Gusti, A. I., \& Oka, A. (2020). The Positive Impact of Problem Based Learning Model Toward Students , Science Knowledge Competence. 4(4), 589595.

7. Kuratko, D. F., Fisher, G., \& Audretsch, D. B. (2020). Unraveling the entrepreneurial mindset. Small Business Economics, June. https://doi.org/10.1007/s11187-020-00372-6

8. Nazri, M. A. at al. (2016). Examination of Factors Affecting Youths' Entrepreneurial Intention: A Cross-Sectional Study. Information Management and Business Review, 8(5), 82-99.

9. Noviyana, H. (2017). Pengaruh Model Project Based Learning Terhadap Kemampuan Berpikir Kreatif Matematika Siswa. JURNAL E-DuMath, 3(2). https://doi.org/10.26638/je.455.2064

10. Rahmazatullaili, R., Zubainur, C. M., \& Munzir, S. (2017). Kemampuan berpikir kreatif dan pemecahan masalah siswa melalui penerapan model project based learning. Beta: Jurnal Tadris Matematika, $10(2)$, 166-183. https://doi.org/10.20414/betajtm.v10i2.104

11. Saptono, A., Wibowo, A., Narmaditya, B. S., Karyaningsih, R. P. D., \& Yanto, H. (2020). Does entrepreneurial education matter for Indonesian students' entrepreneurial preparation: The mediating 
Efa Wahyu Prastyaningtyas et.al. Implementation of PjBL-based in entrepreneurship subject (project based learning) during the pandemic period.

role of entrepreneurial mindset and knowledge. Cogent Education, 7(1). https://doi.org/10.1080/2331186X.2020.183 6728

12. Suciani, T., Lasmanawati, E., \& Rahmawati, Y. (2018). Pemahaman Model Pembelajaran Sebagai Kesiapan Praktik Pengalaman Lapangan (Ppl) Mahasiswa Program Studi Pendidikan Tata Boga. Media Pendidikan, Gizi, Dan Kuliner, 7(1), 76-81.
How to cite this article: Prastyaningtyas EW, Wulansari W. Implementation of PjBL-based in entrepreneurship subject (project based learning) during the pandemic period. International Journal of Research and Review. 2021; 8(9): 474-480. DOI: https://doi.org/10. 52403/ijrr.20210960 